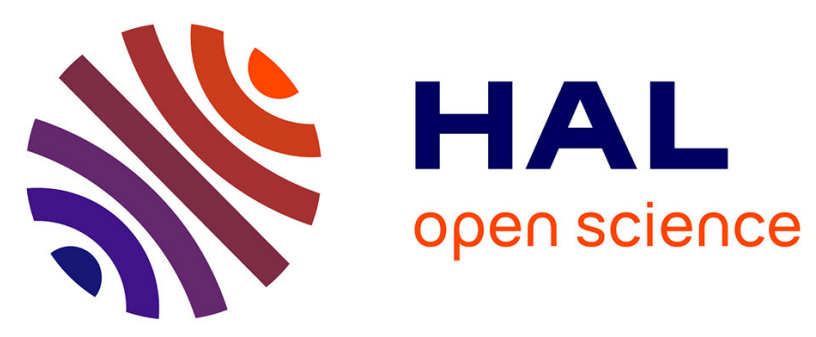

\title{
Molecular and Material Engineering of Photocathodes Derivatized with Polyoxometalate-Supported Mo3S4 HER Catalysts
}

\author{
Jeoffrey Tourneur, Bruno Fabre, Gabriel Loget, Antoine Vacher, Cristelle \\ Mériadec, Soraya Ababou-Girard, Francis Gouttefangeas, Loïc Joanny, \\ Emmanuel Cadot, Mohamed Haouas, et al.
}

\section{To cite this version:}

Jeoffrey Tourneur, Bruno Fabre, Gabriel Loget, Antoine Vacher, Cristelle Mériadec, et al.. Molecular and Material Engineering of Photocathodes Derivatized with Polyoxometalate-Supported Mo3S4 HER Catalysts. Journal of the American Chemical Society, 2019, 141 (30), pp.11954-11962. 10.1021/jacs.9b03950 . hal-02278037

\section{HAL Id: hal-02278037 \\ https://hal-univ-rennes1.archives-ouvertes.fr/hal-02278037}

Submitted on 11 Oct 2019

HAL is a multi-disciplinary open access archive for the deposit and dissemination of scientific research documents, whether they are published or not. The documents may come from teaching and research institutions in France or abroad, or from public or private research centers.
L'archive ouverte pluridisciplinaire HAL, est destinée au dépôt et à la diffusion de documents scientifiques de niveau recherche, publiés ou non, émanant des établissements d'enseignement et de recherche français ou étrangers, des laboratoires publics ou privés. 


\title{
Molecular and Material Engineering of Photocathodes Derivatized with Polyoxometalate Supported- $\left\{\mathrm{Mo}_{3} \mathrm{~S}_{4}\right\}$ HER Catalysts
}

\author{
Jeoffrey Tourneur,§ Bruno Fabre, ${ }^{*} \S$ Gabriel Loget,§ Antoine Vacher,§ Cristelle Mériadec, † Soraya
} Ababou-Girard, ${ }^{\dagger}$ Francis Gouttefangeas, ${ }^{\ddagger}$ Loic Joanny, ${ }^{\ddagger}$ Emmanuel Cadot, ${ }^{*}, \|$ Mohamed Haouas, $\|$ Nathalie Leclerc-Laronze, \| Clément Falaisell and Emmanuel Guillon`

§ Univ Rennes, CNRS, ISCR (Institut des Sciences Chimiques de Rennes)-UMR 6226, F-3500o Rennes, France.

† Univ Rennes, CNRS, IPR (Institut de Physique de Rennes)-UMR6251, F-3500o Rennes, France.

‡ Univ Rennes, CNRS, ScanMAT-CMEBA -UMS2001, F-350oo Rennes, France

\|I Institut Lavoisier de Versailles (UMR-CNRS 8180), UVSQ, Université Paris-Saclay, 45 Avenue des Etats-Unis, 78000 Versailles, France

ๆ Université Reims Champagne Ardenne, Institut de Chimie Moléculaire de Reims (ICMR), UMR 7312 CNRS-URCA, Moulin de la Housse, BP 1039, 51687 Reims Cedex 2, France

\begin{abstract}
Molecular engineering of efficient HER catalysts is an attractive approach for controlling the spatial environment of specific building units selected for their intrinsic functionality required within the multistep HER process. As the $\left\{\mathrm{Mo}_{3} \mathrm{~S}_{4}\right\}$ core derived as various coordination complexes has been identified as one as the most promising $\mathrm{MoS}_{\mathrm{x}^{-}}$ based HER electrocatalysts, we demonstrate that the covalent association between the $\left\{\mathrm{Mo}_{3} \mathrm{~S}_{4}\right\}$ core and the redox-active macrocyclic $\left\{\mathrm{P}_{8} \mathrm{~W}_{48}\right\}$ polyoxometalate (POM) produces a striking synergistic effect featured by high HER performance. Various experiments carried out in homogeneous conditions showed that this synergistic effect arises from the direct connection between the $\left\{\mathrm{Mo}_{3} \mathrm{~S}_{4}\right\}$ cluster and the toroidal $\left\{\mathrm{P}_{8} \mathrm{~W}_{48}\right\}$ units featured by a stoichiometry which can be tuned from two to four $\left\{\mathrm{Mo}_{4} \mathrm{~S}_{4}\right\}$ cores per $\left\{\mathrm{P}_{8} \mathrm{~W}_{48}\right\}$ unit. In addition, we report that this effect is preserved within heterogeneous photoelectrochemical devices where the $\left\{\mathrm{Mo}_{3} \mathrm{~S}_{4}\right\}-\left\{\mathrm{P}_{8} \mathrm{~W}_{48}\right\}$ (thio-POM) assembly was used as co-catalyst (cocat) onto a microstructured $p$-type silicon. Using drop-casting procedure to immobilize cocat onto the silicon interface led to high initial HER performance under simulated sunlight achieving a photocurrent density of $10 \mathrm{~mA} . \mathrm{cm}^{-2}$ at $+0.13 \mathrm{~V} v s$ RHE. Furthermore, electrostatic incorporation of the thio-POM anion cocat into a poly(3,4-ethylenedioxythiophene) (PEDOT) film is demonstrated to be efficient and straightforward to durably retain the cocat at the interface of a micropyramidal silicon (SimPy) photocathode. The thio-POM/PEDOT-modified photocathode is able to produce $\mathrm{H}_{2}$ under 1 Sun illumination at a rate of ca. $100 \mu \mathrm{mol} \mathrm{cm} \mathrm{cm}^{-2} \mathrm{~h}^{-1}$ at o $\mathrm{V} v s$ RHE, highlighting the excellent performance of this photoelectrochemical system.
\end{abstract}

\section{Introduction}

The development of a large scale economically viable technology based on the photochemical water splitting requires upstream implementations to identify efficient and robust catalytic interfaces able to carry out water decomposition into hydrogen and oxygen under harsh conditions. Among the processes able to promote artificial water splitting, sunlightdriven electrochemical reaction provides an exciting solution to convert solar energy into clean fuel such as hydrogen. Then photo-assisted electrochemical reduction of protons (HER) represents nowadays a highly promising eco-friendly route towards clean fuels of high-density energy. ${ }^{1,2,3}$ In context of solar fuels, silicon (bandgap of $1.12 \mathrm{eV}$ ) has appeared as one of the most promising semiconducting materials to be used as a photocathode because its abundance, biocompatibility and ability to harvest photons from a large portion of the solar spectrum, as well as its tunable electronic properties. ${ }^{4,5}$ Nevertheless, bare semiconducting silicon as photocathode exhibits weak HER efficiency, featured by low overpotentials concomitantly with modest HER rates.

Therefore, the immobilization of an appropriate co-catalyst (cocat) onto the photocathode surface is required to increase the HER catalytic efficiency. ${ }^{5,6}$ Noble metals such as platinum exhibit high HER efficiency but its scarcity and high related cost have stimulated intensive research in exploring other noble metal-free and abundant alternatives. In that context, silicon 
photocathodes derivatized with molybdenum sulfide-based complexes, such as molybdenum disulfide $\left(\mathrm{MoS}_{\mathrm{x}}\right)^{7,8,9,10,11,12,13,14}$ and molecular derivatives ${ }^{15,16}$ including the cuboidal molecular clusters $\left\{\mathrm{Mo}_{3} \mathrm{~S}_{4}\right\}^{4+}$ core, ${ }^{17,18}$ have demonstrated high catalytic efficiency for sunlight-driven HER. More generally, molybdenum-sulfide based materials, known as standard industrial catalysts for the hydrodesulphurization heterogeneous process of oils, are emerging as one of the most credible candidates for the electro- or photo-catalytic HER processes. In addition to the $\mathrm{MoS}_{\mathrm{x}}$ electropolymerization onto the electrode surface, the molecular approach using discrete thiomolybdate clusters to mimic the catalytic sites at the $\mathrm{MoS}_{2}$ surface is probably a promising strategy, even though it corresponds to a well-established and conventional approach developed in the 80's in the context of the fossil oils refinery. ${ }^{19}$ In this publication, we report on results arising from a new paradigm that allows designing a breakthrough generation of catalytic materials, engineered as function of the elementary HER principles involving concerted proton/electron transfers (PECT) prior to hydrogen evolution. Linking electroactive molybdenum-sulfur clusters to electron/proton storage units at the molecular level can be achieved taking benefit of the rich coordination chemistry arisen from the $\left\{\mathrm{Mo}_{3} \mathrm{~S}_{4}\right\}$ core combined to polyoxometalate ions. Basically, polyoxometalate (POM) compounds such as metatungstate ion $\left[\mathrm{H}_{2} \mathrm{~W}_{12} \mathrm{O}_{40}\right]^{6-}$ have been featured as electrons sponges capable to exchange up to 32 electrons (and protons) without any significant structural change. ${ }^{20,21,22}$ Such striking properties led naturally to the use of polyoxometalate materials as active components for electrochemical applications such as lithium ions batteries ${ }^{23} \mathrm{In}$ the HER context, polyoxometalates could be envisioned as electron/proton collecting modules associated to $\mathrm{MoS}_{\mathrm{x}}$ catalytic unit able to convert collected electrons and protons into hydrogen. Actually, synthetic strategies have been developed to access the so-called thio-POMs including the $\left\{\mathrm{Mo}_{3} \mathrm{~S}_{4}\right\}$ or $\left\{\mathrm{Mo}_{2} \mathrm{O}_{2} \mathrm{~S}_{2}\right\}$ cores, as constitutional unit, linker or template within the metal-oxo framework. ${ }^{24,25}$ Thus, such hybrid oxysulfide molecular compounds have been considered recently as cost-effective catalysts for HER immobilized on silicon surfaces. ${ }^{26}$ Interestingly, the thio-POM-modified silicon photocathodes exhibited enhanced long-term stability compared with electrodes integrating the parent $\left\{\mathrm{Mo}_{3} \mathrm{~S}_{4}\right\}$ cluster derived as coordination complexes. ${ }^{26}$

Herein, we report on the remarkable and significant synergistic catalytic effect arising from the grafting of the $\left[\mathrm{Mo}_{3} \mathrm{~S}_{4}\left(\mathrm{H}_{2} \mathrm{O}\right)_{9}\right]^{4+}$ (abbreviated as $\left\{\mathrm{Mo}_{3} \mathrm{~S}_{4}\right\}$ ) onto the robust macrocyclic polyoxotungstate $\left[\mathrm{H}_{7} \mathrm{P}_{8} \mathrm{~W}_{48} \mathrm{O}_{184}\right]^{33-}$ (noted $\left\{\mathrm{P}_{8} \mathrm{~W}_{48}\right\}$ ). This remarkable increase of the HER efficiency was first evidenced in homogeneous conditions using carbon-based electrodes and then transposed successfully in heterogeneous conditions using modified silicon photocathodes. In addition, we show that the standard drop-casting method employed for depositing the cocat on the electrode surface results in weak attractive interactions that lead to the partial release of the cocat from the silicon surface. ${ }^{26}$ We thus report an effective method to improve the time stability of the photocathode by using the electrostatic entrapment of the negatively charged thio-POM into a cationic polymer film, namely poly(3,4-ethylenedioxythiophene) (PEDOT). This method is applied on microstructured silicon surfaces ${ }^{12,17,27,28}$ in order to considerably improve light absorption to yield robust photocathodes with appreciable solar-driven HER activity observed above $0 \mathrm{~V}$ vs Reversible Hydrogen Electrode (RHE).
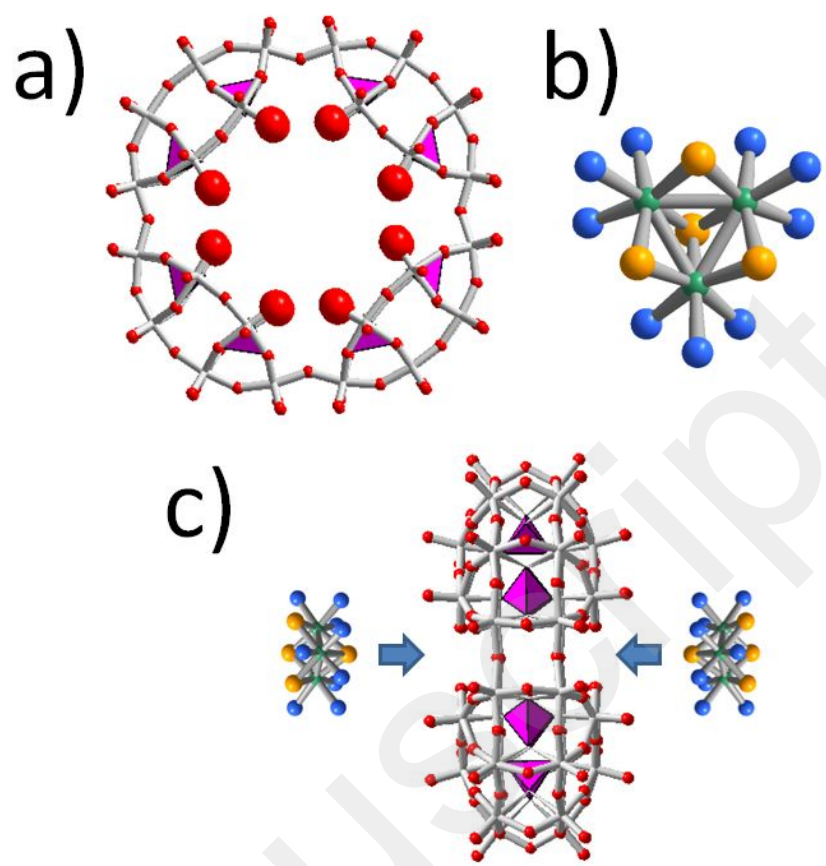

Figure 1. a) Structural representation of the $\left[\mathrm{H}_{7} \mathrm{P}_{8} \mathrm{~W}_{48} \mathrm{O}_{184}\right]^{33-}$ anion resulting from the cyclic connection of four $\left\{\mathrm{P}_{2} \mathrm{~W}_{12} \mathrm{O}_{48}\right\}$ subunits. The large central cavity is lined on the both faces by eight nucleophlic oxo/hydroxo groups. b) Structure of the aqua ion $\left[\mathrm{Mo}_{3} \mathrm{~S}_{4}\left(\mathrm{H}_{2} \mathrm{O}\right)_{9}\right]^{4+}$ showing the nine labile aqua ligands able to be exchanged for nucleophilic oxo groups belonging to POM unit. c) Schematic view of reacting species i.e electrophilic and nucleophilic units leading to the $\left\{\mathrm{P}_{8} \mathrm{~W}_{48}\right\}$-supported $\left\{\mathrm{Mo}_{3} \mathrm{~S}_{4}\right\}$ electrocatalysts.

\section{Results and Discussion}

2.1. Formation and characterization of the catalytic $\boldsymbol{M o}_{3} \boldsymbol{S}_{4} \boldsymbol{P}_{8} \boldsymbol{W}_{48}$ adduct. $\left\{\mathrm{P}_{8} \mathrm{~W}_{48}\right\}$ POM ion exhibits a large toric arrangement built from the cyclic connections of four $\left\{\mathrm{P}_{2} \mathrm{~W}_{12} \mathrm{O}_{48}\right\}$ subunits that delimit a large cavity of about $12 \AA$ in diameter (Figure 1). ${ }^{29}$ The metal-oxo backbone of the $\left\{\mathrm{P}_{8} \mathrm{~W}_{48}\right\}$ ion is stable over a large $\mathrm{pH}$ scale leading to a large diversity of protonation states varying from 16 at $\mathrm{pH}<1$ to 7-8 at $\mathrm{pH}=4.8 .{ }^{30}$ This ion has been described as "superlacunary" species, due to its striking ability to entrap a large variety of guests. Thus, various metallic cations, such as copper, iron, cobalt or lanthanides and recently actinides have been included and characterized as inner polymetallic clusters closely entrapped within the central cavity. ${ }^{31,32,33}$ Using bulkier polymetallic groups featured by specific coordination requirement led to a distinct scenario. For instance, with the $\left[\mathrm{Mo}_{2} \mathrm{E}_{2} \mathrm{~S}_{2}\left(\mathrm{H}_{2} \mathrm{O}\right)_{6}\right]^{2+}$ aqua cations (with $\mathrm{E}=\mathrm{O}$ or S), the resulting species correspond to the $\left\{\mathrm{P}_{8} \mathrm{~W}_{48}\right\}$ skeleton capped on both sides of the torus by two symmetric tetranuclear aggregates $\left[\mathrm{Mo}_{4} \mathrm{E}_{4} \mathrm{O}_{4}(\mathrm{OH})_{2}\left(\mathrm{H}_{2} \mathrm{O}\right)_{3}\right]$ acting as basket handles. ${ }^{34,35}$ In such an assembly, the large $\left\{\mathrm{P}_{8} \mathrm{~W}_{48}\right\}$ anion can be viewed as a redoxactive support allowing the immobilization of the $\left\{\mathrm{MoS}_{\mathrm{x}}\right\}$ species through the eight oxo/hydroxo groups which line both sides of the central hole (Fig. 1). Actually, as previously reported, the $\left\{\mathrm{P}_{8} \mathrm{~W}_{48}\right\}$ anion is able to exchange reversibly and simultaneously up to sixteen electrons/protons under acid conditions ( $\mathrm{pH}=1-3)$, in three reversibly 4/4/8-electron transfer steps within a narrow potential range. Herein, a similar methodology has been applied using the $\left\{\mathrm{Mo}_{3} \mathrm{~S}_{4}\right\}$ aqua ion as 
grafted species and consists to condense the electrophilic thiomolybdic aqua cation on the $\left\{\mathrm{P}_{8} \mathrm{~W}_{48}\right\}$ surface.
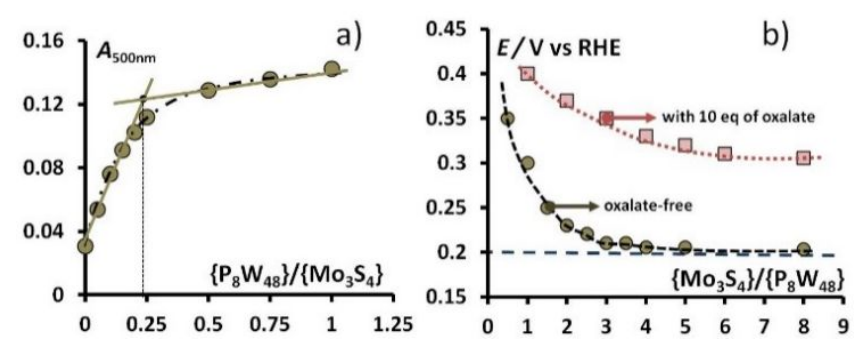

Figure 2. a) UV-vis titration of $\left\{\mathrm{Mo}_{3} \mathrm{~S}_{4}\right\}$ solution by $\left\{\mathrm{P}_{8} \mathrm{~W}_{48}\right\}$ : variation of the absorbance at $500 \mathrm{~nm}$ shows a breaking-point corresponding to four $\left\{\mathrm{Mo}_{3} \mathrm{~S}_{4}\right\}$ per $\left\{\mathrm{P}_{8} \mathrm{~W}_{48}\right\}$. b) Electrochemical titration of a $\left\{\mathrm{P}_{8} \mathrm{~W}_{48}\right\}$ solution by $\left\{\mathrm{Mo}_{3} \mathrm{~S}_{4}\right\}$ unit. The electrocatalytic HER overpotential measured at a fixed current decreases continuously until a plateau corresponding to the limiting stoichiometry $4\left\{\mathrm{Mo}_{3} \mathrm{~S}_{4}\right\}+\left\{\mathrm{P}_{8} \mathrm{~W}_{48}\right\}$. In the presence of oxalate ion (oxalate $/\left\{\mathrm{Mo}_{3} \mathrm{~S}_{4}\right\}=10$ ), the synergistic effect arising from $\left\{\mathrm{P}_{8} \mathrm{~W}_{48}\right\}$ support and the $\left\{\mathrm{Mo}_{3} \mathrm{~S}_{4}\right\}$ cluster appears partially cancelled.

Reaction was carried out in $\mathrm{pH}=1$ aqueous solution and led to a clear color change from olive-green to yellow-brown. $\left\{\mathrm{Mo}_{3} \mathrm{~S}_{4}\right\}-\left\{\mathrm{P}_{8} \mathrm{~W}_{48}\right\}$ solutions gave the characteristic absorptions in the visible region of the $\left\{\mathrm{Mo}_{3} \mathrm{~S}_{4}\right\}$ chromophore while the $\left\{\mathrm{P}_{8} \mathrm{~W}_{48}\right\}$ ion absorbed below $380 \mathrm{~nm}$. UV-vis titration of $\left\{\mathrm{Mo}_{3} \mathrm{~S}_{4}\right\}$-containing solutions with POM showed a significant increase of the absorbance as the $\mathrm{POM} /\left\{\mathrm{Mo}_{3} \mathrm{~S}_{4}\right\}$ ratio increased until a break-point observed for $\mathrm{POM} /\left\{\mathrm{Mo}_{3} \mathrm{~S}_{4}\right\}=0.25$, corresponding to a limiting stoichiometry of four $\left\{\mathrm{Mo}_{3} \mathrm{~S}_{4}\right\}$ units per POM moiety (Figure $2 \mathrm{a}$ and Figure $\mathrm{S} 1$ in the Electronic Supporting Information). Besides, change of the electronic spectra features modifications of the coordination spheres of the Mo centers occurring through the grafting process, such as substitutions of some aquo ligands for oxo groups of the POM subunit. Furthermore, the limit stoichiometry corresponding to four $\left\{\mathrm{Mo}_{3} \mathrm{~S}_{4}\right\}$ cores per $\left\{\mathrm{P}_{8} \mathrm{~W}_{48}\right\}$ unit appears consistent with two $\left\{\mathrm{Mo}_{3} \mathrm{~S}_{4}\right\}$ cores grafted on each face of the $\left\{\mathrm{P}_{8} \mathrm{~W}_{48}\right\}$, involving the eight nucleophilic oxo groups that line the both sides of the central cavity (Figure 1). Such a type of arrangement should be similar to that found within the $\left\{\mathrm{Mo}_{2} \mathrm{O}_{2} \mathrm{~S}_{2}\right\}$-containing $\left\{\mathrm{P}_{8} \mathrm{~W}_{48}\right\} .{ }^{35}$ Synthetic procedures were established allowing getting solids as potassium acidic salts with $\left\{\mathrm{Mo}_{3} \mathrm{~S}_{4}\right\}$ content varying from zero up to four equivalents (see ESI). Despite numerous attempts, getting single crystals for $\mathrm{X}$-ray diffraction analysis failed whatever the applied conditions $\left(\mathrm{pH},\left\{\mathrm{Mo}_{3} \mathrm{~S}_{4}\right\} / \mathrm{POM}\right.$ ratio, ionic strength, nature of the counter ions...). Such a result can be explained in part by ${ }^{31} \mathrm{P}$ NMR study which showed complex spectra featured by many signals ranging from about -6 to -9 ppm responsible of the collapse of the NMR response, while the $\left\{\mathrm{P}_{8} \mathrm{~W}_{48}\right\}$ precursor gave a single sharp line at $-6.5 \mathrm{ppm}$ in aqueous solution (Figures $\mathrm{S} 2$ and S3). This observation is rather consistent with statistical distributions of $\left\{\mathrm{Mo}_{3} \mathrm{~S}_{4}\right\}$ species over the two faces of the toroidal support producing several species and isomers. Nevertheless, the substantial broadening of the ${ }^{31} \mathrm{P}$ resonances could also reflect the dynamic behavior of these $\left\{\mathrm{Mo}_{3} \mathrm{~S}_{4}\right\}$ clusters on the POM surface. Actually, the large number of generated species and their related dynamics should favor the formation of amorphous precipitates rather than well-defined molecular species included within single-crystal materials. Infrared spectra of the resulting mixed potassium-lithium acidic salts remained nearly unchanged between the $\left\{\mathrm{P}_{8} \mathrm{~W}_{48}\right\}$ precursor and the $\left\{\mathrm{Mo}_{3} \mathrm{~S}_{4}\right\}$-containing compounds, which suggests the full retention of the metal-oxo framework in the presence of the $\left\{\mathrm{Mo}_{3} \mathrm{~S}_{4}\right\}$-supported cluster (Figure S4). In short, the reported solution studies demonstrate that the $\left\{\mathrm{Mo}_{3} \mathrm{~S}_{4}\right\}$ aqua cation interacts with $\left\{\mathrm{P}_{8} \mathrm{~W}_{48}\right\}$ surface leading to the $\left\{\mathrm{P}_{8} \mathrm{~W}_{48}\right\}$ supported $\left\{\mathrm{Mo}_{3} \mathrm{~S}_{4}\right\}$ catalytic materials which can differ in their $\left\{\mathrm{Mo}_{3} \mathrm{~S}_{4}\right\}$ loading, ranging from 0 to $4\left\{\mathrm{Mo}_{3} \mathrm{~S}_{4}\right\}$ cores per POM unit. Molecular materials featured by three $\left\{\mathrm{Mo}_{3} \mathrm{~S}_{4}\right\}$ clusters per $\left\{\mathrm{P}_{8} \mathrm{~W}_{48}\right\}$ unit have been isolated through straightforward procedures giving either a water soluble mixed potassium acidic salt $\mathrm{K}_{15} \mathrm{H}_{13} \mathrm{P}_{8} \mathrm{~W}_{48}\left(\mathrm{Mo}_{3} \mathrm{~S}_{4}\right)_{3} \mathrm{O}_{184} \quad$ • $\quad 89 \mathrm{H}_{2} \mathrm{O} \quad$ (1a) or $\quad$ a tetrabutylammonium salt $\left(\mathrm{NBu}_{4}\right)_{14} \mathrm{~K}_{2} \mathrm{H}_{12} \mathrm{P}_{8} \mathrm{~W}_{48}\left(\mathrm{Mo}_{3} \mathrm{~S}_{4}\right)_{3} \mathrm{O}_{184} \bullet$ $60 \mathrm{H}_{2} \mathrm{O}(\mathbf{1 b})$. As compound 1a was used for HER investigations in homogeneous conditions, $\mathbf{1 b}$ was employed for the preparation of cocat-supported silicon HER photocathodes.

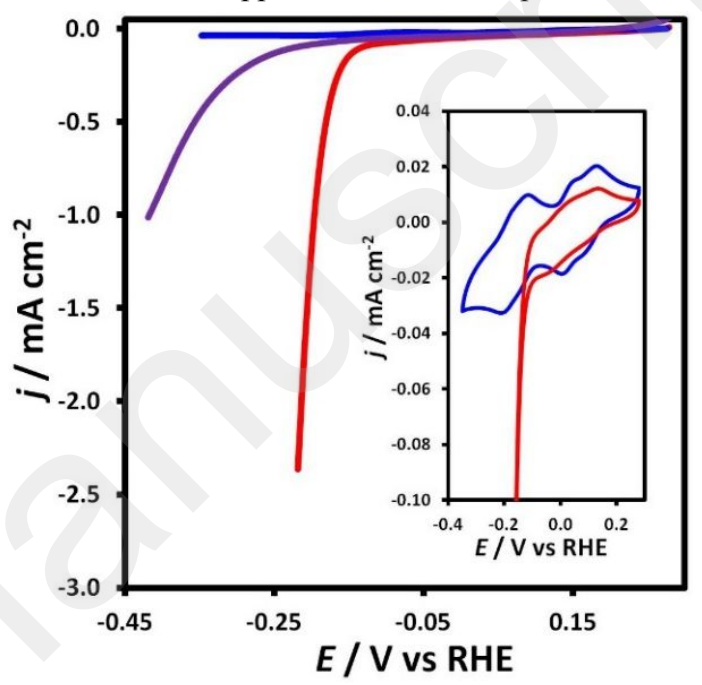

Figure 3. Polarization curves of $5 \times 10^{-4}$ mol L-1 $\left\{\mathrm{P}_{8} \mathrm{~W}_{48}\right\}$ (blue), $\left\{\mathrm{Mo}_{3} \mathrm{~S}_{4}\right\}$ (purple) and 1a (red) recorded on glassy carbon showing the highest efficiency of the hybrid $\left\{\mathrm{P}_{8} \mathrm{~W}_{48}\right\}$-supported $\left\{\mathrm{Mo}_{3} \mathrm{~S}_{4}\right\}$ catalyst in $0.5 \mathrm{~mol} \mathrm{~L}^{-1}$ aqueous sulfate solution $\mathrm{pH}=1$ (scan rate $=50 \mathrm{mV} \mathrm{s}^{-1}$ ). The inset highlights the influence of $\left\{\mathrm{Mo}_{3} \mathrm{~S}_{4}\right\}$ on the redox behavior of the $\left\{\mathrm{P}_{8} \mathrm{~W}_{48}\right\}$ ion. Prior to the HER electrocatalytic discharge, eight electrons and protons are transferred within the $\left\{\mathrm{P}_{8} \mathrm{~W}_{48}\right\}$ subunit.

\subsection{Evidence of the HER synergistic effect within the} $\boldsymbol{M o}_{3} \boldsymbol{S}_{4}-\boldsymbol{P}_{8} \boldsymbol{W}_{48}$ adduct. Investigation of the electrocatalytic HER activity of the $\left\{\mathrm{Mo}_{3} \mathrm{~S}_{4}\right\}$-containing $\left\{\mathrm{P}_{8} \mathrm{~W}_{48}\right\}$ has been conducted first in homogeneous conditions at $\mathrm{pH}=1$. The electrochemical behavior of the $\left\{\mathrm{P}_{8} \mathrm{~W}_{48}\right\}$ anion is wellestablished ${ }^{36}$ and corresponds to three reversible 4/4/8 electrons reduction waves observed at $E^{\circ}=+0.11,0.02$ and $-0.16 \mathrm{~V} v s$ RHE (Figure 3). Furthermore, previous studies have revealed a potential dependency for these three processes of about $-60 \mathrm{mV}$ per $\mathrm{pH}$ unit suggesting a concomitant transfer involving an equal number of electrons and protons. Moreover, no significant HER process was evidenced in this potential range. In contrast, grafting three $\left\{\mathrm{Mo}_{3} \mathrm{~S}_{4}\right\}$ clusters onto the $\left\{\mathrm{P}_{8} \mathrm{~W}_{48}\right\}$ support (compound 1a) provokes a sharp and abrupt exponential increase in the magnitude of the cathodic current that overlaps with the third electron transfer step observed at $-0.16 \mathrm{~V}$ vs RHE (Figure 3). Below $-0.15 \mathrm{~V}$ vs RHE, the characteristic HER activity has been measured showing a direct relationship between the catalytic current and the evolved hydrogen with a faradaic yield up to $95 \%$ (Figure S5). For comparison, the HER electrocatalytic activity of the $\left\{\mathrm{Mo}_{3} \mathrm{~S}_{4}\right\}$ aqua ion measured under similar conditions showed a lower 
efficiency featured by a substantial increase of the overpotential of about $200 \mathrm{mV}$ (Figures 3 and S6). Furthermore, replacing the terminal aqua ligands attached to the three Mo centers by other groups such as oxalate ions (which reproduce roughly the oxo coordinating sphere of the POM) afforded only weak beneficial gain to the $\left\{\mathrm{Mo}_{3} \mathrm{~S}_{4}\right\}$ HER activity (Fig. S6). Therefore, these results evidence a synergistic interplay between the $\left\{\mathrm{P}_{8} \mathrm{~W}_{48}\right\}$ support and the $\left\{\mathrm{Mo}_{3} \mathrm{~S}_{4}\right\}$ catalytic units, which can be understood from the redox behavior and the electronic properties of the POM as a result of delocalization of $4 d$ electrons over the metal-oxo framework through fast hopping process. At last, the electrocatalytic interplay between the $\left\{\mathrm{Mo}_{3} \mathrm{~S}_{4}\right\}$ unit and the POM matrix has been further highlighted through a in situ solution titration of $\left\{\mathrm{P}_{8} \mathrm{~W}_{48}\right\}$ by $\left\{\mathrm{Mo}_{3} \mathrm{~S}_{4}\right\}$ aqua cation (Figures $2 \mathrm{~b}$ and S7). As the number of $\left\{\mathrm{Mo}_{3} \mathrm{~S}_{4}\right\}$ units increases in solution, the HER potential measured arbitrarily at $2.8 \mathrm{~mA} \mathrm{~cm}^{-2}$ decreases continuously until reaching a plateau for the stoichiometry of about four $\left\{\mathrm{Mo}_{3} \mathrm{~S}_{4}\right\}$ units per $\left\{\mathrm{P}_{8} \mathrm{~W}_{48}\right\}$ unit (Fig. 2b). Excess in thiomolybdic cation did not afford any further significant benefit upon the HER efficiency, meaning that the origin of this synergistic HER gain arises from the direct covalent interaction between the $\left\{\mathrm{Mo}_{3} \mathrm{~S}_{4}\right\}$ core and the $\left\{\mathrm{P}_{8} \mathrm{~W}_{48}\right\}$ support. Interestingly, the same titration experiment carried out in the presence of ten equivalents of oxalate per $\left\{\mathrm{Mo}_{3} \mathrm{~S}_{4}\right\}$ unit led to a significantly weaker overpotential gain, reflecting the partial cancellation of this invoked synergistic effect (Figures $2 \mathrm{~b}$ and $\mathrm{S7}$ ). In this case, competition process between oxalate ligands and the $\left\{\mathrm{P}_{8} \mathrm{~W}_{48}\right\}$ anion toward $\left\{\mathrm{Mo}_{3} \mathrm{~S}_{4}\right\}$ coordination limited the formation of the highly efficient thio-POM. To further verify this synergistic interplay, a reverse titration has been carried out, showing the HER performance of the $\left\{\mathrm{Mo}_{3} \mathrm{~S}_{4}\right\}$ core enhanced in the presence of various equivalents of $\left\{\mathrm{P}_{8} \mathrm{~W}_{48}\right\}$ (Figure $\mathrm{S} 8$ ). In this report, we demonstrate through a series of experiments that $\left\{\mathrm{Mo}_{3} \mathrm{~S}_{4}\right\}$ core and $\left\{\mathrm{P}_{8} \mathrm{~W}_{48}\right\}$ polyoxometalate associates their intrinsic electrochemical properties to produce highly efficient thio-POM molecular electrocatalyst.

\subsection{Structured Si photocathodes modified with thio-}

POM. In order to evaluate the possibility of integrating the thio-POM on a silicon photocathode in heterogeneous conditions, glassy carbon was replaced by a photoactive oxidefree $p$-type silicon modified with thio-POM by drop-casting. Resulting photocathodes have been modified using different molecular materials, namely the parent POM $\left\{\mathrm{P}_{8} \mathrm{~W}_{48}\right\}$ ion, the thio-POM derivative $\left\{\left(\mathrm{Mo}_{3} \mathrm{~S}_{4}\right)_{3}\left(\mathrm{P}_{8} \mathrm{~W}_{48}\right)\right\} \mathbf{1 b}$ and the $\left\{\mathrm{Mo}_{3} \mathrm{~S}_{4}\right\}$ core derived as $\left[\mathrm{Mo}_{3} \mathrm{~S}_{4}\left(\mathrm{H}_{2} \mathrm{O}\right)_{3}(\mathrm{acacBu})_{3}\right]^{+}$complex $(\mathrm{acacBu}=$ butyl-acetylacetonate and noted $\left\{\mathrm{Mo}_{3} \mathrm{~S}_{4}\right.$-acacBu$\}$ hereafter). Linear sweep voltammetry (LSV) curves measured under simulated sunlight (AM 1.5G, $100 \mathrm{~mW} \mathrm{~cm} \mathrm{~cm}^{-2}$ ) provided a clear evidence for the superior HER catalytic activity of thio-POM in acidic conditions by comparison of the other respective voltammetric responses (Figure 4).

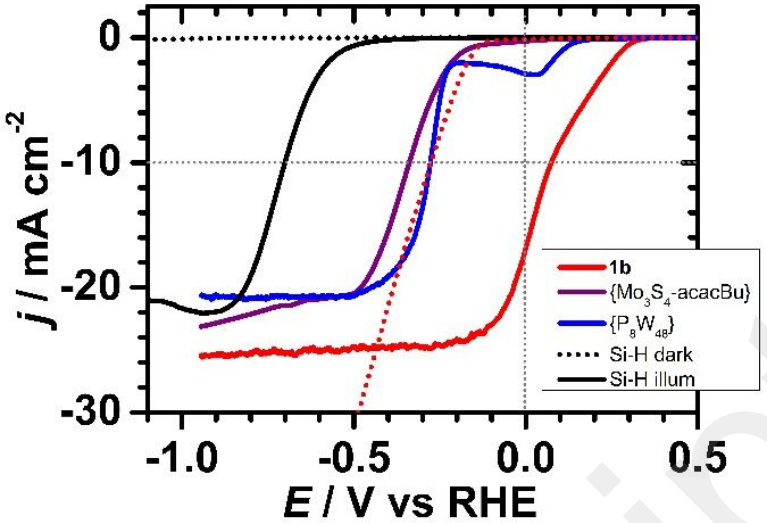

Figure 4. Linear sweep voltammograms at $20 \mathrm{mV} \mathrm{s}^{-1}$ of different catalystmodified flat $p$-type $\mathrm{Si}(100)$ photocathodes under simulated sunlight (AM $\left.1.5 \mathrm{G}, 100 \mathrm{~mW} \mathrm{~cm}^{-2}\right)$ in $1.0 \mathrm{~mol} \mathrm{~L}^{-1} \mathrm{H}_{2} \mathrm{SO}_{4}$. The black and red dotted lines correspond to the LSV curves of photocathodes in the dark and 1b-modified glassy carbon, respectively. The electrodes were prepared by drop-casting of a catalyst solution to reach a loading of $2.9 \times 10^{-5} \mathrm{mmol} \mathrm{cm}^{-2}$.

Indeed, the 1b-modified photocathode showed an overpotential of $+0.07 \mathrm{~V}$ vs RHE (corresponding to $+0.13 \mathrm{~V}$ when the Ohmic drop was corrected, Figure S9) at a photocurrent density of -10 $\mathrm{mA} \mathrm{cm} \mathrm{cm}^{-2}$. We notice that the overpotential value measured at $10 \mathrm{~mA} \mathrm{~cm}{ }^{-2}$ for the $\mathbf{1 b}$-modified photocathode is among the lowest reported so far for thiomolybdate-based HER electrocatalysts immobilized on $p$-type Si photocathodes (Table 1). ${ }^{10,12,17,26,27}$

Table 1. Catalytic Performances of Different $\mathrm{MoS}_{2}$ and Derived Molecular Clusters-Coated $p$-Type Silicon Photocathodes for Simulated Sunlight-Assisted HER ${ }^{a}$

$\begin{array}{llllll}\mathrm{Si} / \text { Catalyst }^{b} & \begin{array}{l}\text { Onset } \\ \text { potential } \\ / \mathrm{V}_{\mathrm{RHE}}{ }^{c}\end{array} & \begin{array}{l}E / \mathrm{V}_{\mathrm{RHE}} \text { at } \\ -10 \mathrm{~mA} \mathrm{~cm}{ }^{-2}\end{array} & \begin{array}{l}-j_{\mathrm{L}} \\ / \mathrm{mA} \mathrm{cm}^{-2} d\end{array} & \mathrm{pH} & \text { Ref } \\ \mathrm{Si}_{\mathrm{NW}} / \mathrm{MoS}_{2} & +0.20 & <-0.20 & -e & 5.0 & 10 \\ \mathrm{Si}_{\mathrm{PL}} / \mathrm{MoS}_{2} & +0.28 & +0.10 & 26.5 & 0.0 & 11 \\ \mathrm{Si}_{\mathrm{PL}} / \mathrm{Mo}_{3} \mathrm{~S}_{4} & +0.15 & -0.05 & 10.5 & 0.0 & 17 \\ \mathrm{Si}_{\mathrm{PIL}} / \mathrm{Mo}_{3} \mathrm{~S}_{4} & +0.15 & \sim 0.00 & 14 & 0.0 & 17 \\ \mathrm{Si}_{\mathrm{PL}} / \mathrm{Mo}_{3} \mathrm{~S}_{4} & -0.04 & -0.45 & 25.8 & 0.3 & 26 \\ \mathrm{Si}_{\mathrm{PL}} /\left\{\mathrm{Mo}_{3} \mathrm{~S}_{4}\right\} & -0.02 & -0.37 & 21.5 & 0.3 & 26 \\ \left\{\mathrm{AsW}_{12}\right\} & & & & & \\ \mathrm{Si}_{\mathrm{mPy} /\left\{\mathrm{Mo}_{3} \mathrm{~S}_{4}\right\}}+0.33 & +0.07 & 25.0 & 0.3 & \text { This } \\ \left\{\mathrm{P}_{8} \mathrm{~W}_{48}\right\} & & & & & \text { work }\end{array}$

${ }^{a}$ The electrodes based on $\mathrm{n}^{+} \mathrm{p}$-Si junctions have been deliberately omitted and the indicated potentials are Ohmic drop-uncorrected. ${ }^{b} \mathrm{PL}$ : planar silicon, PIL: silicon pillars, MWs: microwires, NWs: nanowires and mPy: micropyramids. ${ }^{c}$ Determined for a current density of $0.25 \mathrm{~mA} \mathrm{~cm}{ }^{-}$ ${ }^{2}$. $d$ Plateau current density corresponding to the light-limited catalytic current. ${ }^{e}$ Not indicated.

The slight differences observed in the light-limited photocurrent densities between the catalysts are attributed mainly to differences in both the amount of deposited catalytic material and light absorption. Importantly, these results demonstrate that the synergistic effect arising from the $\left\{\mathrm{Mo}_{3} \mathrm{~S}_{4}\right\}-\left\{\mathrm{P}_{8} \mathrm{~W}_{48}\right\}$ combination can be transposed from the homogeneous to the heterogeneous phases. Furthermore, this striking thio-POM synergistic effect is even amplified when the catalytic material was deposited on a silicon photocathode. Indeed, under such conditions, the $\left\{\mathrm{Mo}_{3} \mathrm{~S}_{4}\right\}-\left\{\mathrm{P}_{8} \mathrm{~W}_{48}\right\}$ association leads to a net decrease of the overpotential of about ca. $400 \mathrm{mV}$ compared with the other cocat-modified 
illuminated silicon photocathodes while in homogeneous conditions using glassy carbon as the cathode, the decrease of the overpotential never exceeded ca. $200 \mathrm{mV}$ (Fig. 3). Besides, a net photovoltage of $c a .430 \mathrm{mV}$ is measured from the difference between the onset potentials of $\mathbf{1 b}$-modified reference glassy carbon and illuminated $\mathrm{Si}$ electrodes, highlighting the activation of the electrocatalytic process by electrons photogenerated at the semiconductor.

Despite these promising intrinsic catalytic features, the 1bmodified photocathode was electrochemically unstable as evidenced by the fast degradation of the photocurrent response upon electrochemical cycling (Figure S10). A dramatic decrease of the onset potential from 0.33 to $0.06 \mathrm{~V} v s$ RHE was observed after ten successive LSV scans. A similar trend was noticed for the two other $\left\{\mathrm{P}_{8} \mathrm{~W}_{48}\right\}$ and $\left\{\mathrm{Mo}_{3} \mathrm{~S}_{4}\right.$-acacBu$\}$ modified photocathodes. Such a behavior was attributed to the release of the catalytic material from the electrode interface into the electrolytic solution, as previously reported for other thiomolybdate ${ }^{17,37}$ - or thio-POM ${ }^{26}$-modified surfaces. Consequently, in order to retain more durably the catalytic material grafted on the semiconducting surface, $\mathbf{1 b}$ was electrostatically entrapped into a PEDOT film taking advantage of the anionic charge of the catalyst and the strong affinity of PEDOT for large multivalent anions. ${ }^{38}$ Experimentally, a solution containing $\mathbf{1 b}$ and PEDOT (Figure S11) was used for the deposition of the catalytic material. Indeed, the EDOT electropolymerization method must be precluded to avoid any oxidation of the underlying silicon surface that would occur inevitably at the anodic potentials required to promote EDOT polymerization. Moreover, a microstructured silicon surface was selected as the immobilization substrate, namely micropyramid (SimPy) arrays, instead of flat Si to increase the surface area of the photocathode (and therefore its photoelectrochemical activity) counterbalancing the antagonist effect of PEDOT absorption in the visible region (vide infra). SimPy array was fabricated through alkaline etching of $p$-type $\mathrm{Si}$ (100) surfaces, which resulted in the formation of pyramids ranging from 5 to $15 \mu \mathrm{m}$ heights (see ESI for experimental details and Figure S12 for an illustrative SEM cross-section view). The SEM analysis of the 1b/PEDOT-modified surfaces showed a ca. 200-300 nm-thick porous and cracked material layer covering not homogeneously the SimPy array (Figure 5). We anticipate that such an aerated structure should facilitate the removal of $\mathrm{H}_{2}$ gas bubbles during electrolytic HER tests (vide infra).
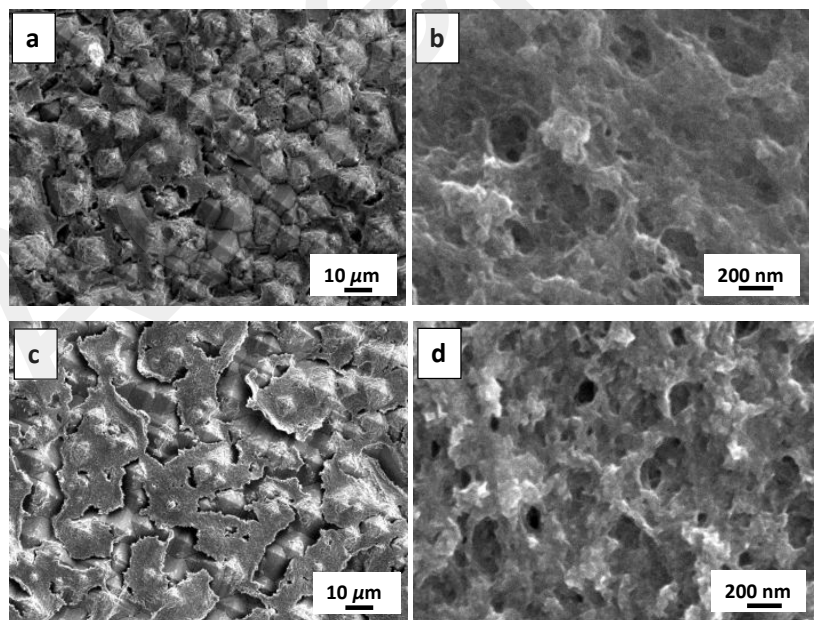

Figure 5. SEM pictures of $\mathbf{1 b} / \mathrm{PEDOT}$-coated $\operatorname{SimPy}$ before $(\mathrm{a}, \mathrm{b})$ and after electrolysis at $0 \mathrm{~V}$ vs RHE for $3 \mathrm{~h}$ in $1 \mathrm{M} \mathrm{H}_{2} \mathrm{SO}_{4}(\mathrm{c}, \mathrm{d})$.

The X-ray photoelectron spectroscopy (XPS) analysis of the doped polymer-modified surface confirmed the entrapment of the thio-POM in the PEDOT matrix. The survey spectrum showed all characteristic peaks related to both components of the catalytic material i.e. organic and inorganic parts (Figure $\mathrm{S} 13$ ). The high-resolution $\mathrm{C} 1 \mathrm{~s}$ spectrum could be reasonably fitted using five components at 285.0, 285.3, 286.1, 286.9 and $288.1 \mathrm{eV}$ corresponding to different carbon atoms present in the EDOT pattern, namely $\mathrm{C}-\mathrm{C} / \mathrm{C}-\mathrm{H}, \mathrm{C}-\mathrm{S}$ in the $\alpha$ position, $\mathrm{C}=\mathrm{C}-\mathrm{O}$ in the $\beta$ position and $\mathrm{C}-\mathrm{O}-\mathrm{C}$ in the ethylene bridge, respectively, and to the $\pi \rightarrow \pi^{*}$ shake-up transition of the aromatic ring, as well (Figure 6a). ${ }^{39,40,41}$ The main Mo $3 \mathrm{~d}_{5 / 2}$ and Mo $3 \mathrm{~d}_{3 / 2}$ lines at 230.1 and $233.0 \mathrm{eV}$ were consistent with molybdenum in the formal +IV state (Figure 6b). ${ }^{42}$ The S 2 s signal showed two components at 226.7 and $228.2 \mathrm{eV}$ which are characteristic of sulfur in thio-POM and in the thiophene ring, ${ }^{43}$ respectively. The $S$ 2p spectrum could be deconvoluted into three spin-split doublets, $2 \mathrm{p}_{3 / 2}$ and $2 \mathrm{p}_{1 / 2}$, with an energy splitting of $1.2 \mathrm{eV}$ and an intensity ratio of 1:2, as theoretically expected (Figure 6d).
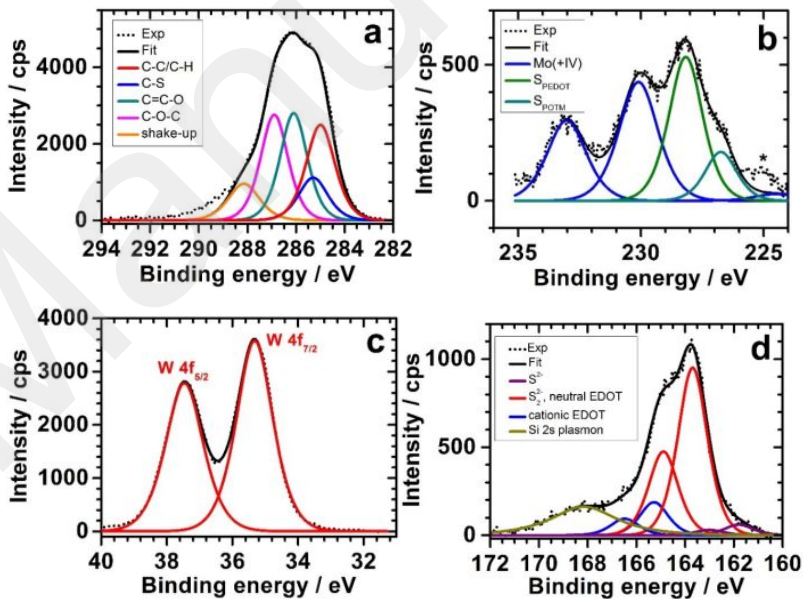

Figure 6. C 1s (a), Mo $3 \mathrm{~d}$ and $\mathrm{S} 2 \mathrm{~s}(\mathrm{~b}), \mathrm{W} 4 \mathrm{f}$ (c) and $\mathrm{S} 2 \mathrm{p}$ (d) high-resolution spectra of 1b/PEDOT-coated SimPy. Experimental data and fitting envelopes are represented by black dotted and solid lines, respectively. The peak observed at ca. $225 \mathrm{eV}$ (indicated by an asterisk) is attributed to a satellite peak intrinsic to the used XPS source. The colored lines are fitted curves using Gaussian-Lorentzian mixed peaks corresponding to different components.

The broad signal observed at $168.2 \mathrm{eV}$ was attributed to the plasmon loss peak of Si $2 \mathrm{~s}$. The first doublet at $161.8 \mathrm{eV}(\mathrm{S}$ $\left.2 \mathrm{p}_{3 / 2}\right)$ and $163.0 \mathrm{eV}\left(\mathrm{S} 2 \mathrm{p}_{1 / 2}\right)$ could be ascribed to $\mathrm{S}^{2-}$ ligands of thio-POM ${ }^{26,44,45}$ while the two other ones at $163.7 / 164.9 \mathrm{eV}(\mathrm{S}$ $2 \mathrm{p}_{3 / 2} / \mathrm{S} 2 \mathrm{p}_{1 / 2}$ ) and $165.3 / 166.5 \mathrm{eV}$ corresponded to the contributions of $\mathrm{S}_{2}{ }^{2-}$ units of thio-POM and neutral EDOT sulfur, ${ }^{39,41}$ and positively charged EDOT sulfur, ${ }^{41}$ respectively. The $\mathrm{W} 4 \mathrm{f}$ and $\mathrm{W} 4 \mathrm{~d}$ lines observed at $35.3\left(\mathrm{~W} 4 \mathrm{f}_{7 / 2}\right), 37.5$ (W $\left.4 \mathrm{f}_{5 / 2}\right), 247.7\left(\mathrm{~W} \mathrm{4d_{5/2 }}\right)$, and $260.5\left(\mathrm{~W} 4 \mathrm{~d}_{3 / 2}\right) \mathrm{eV}$ were consistent with $\mathrm{W}-\mathrm{O} / \mathrm{W}=\mathrm{O}$ species involving tungsten in the formal $+\mathrm{VI}$ state (Figures $6 \mathrm{c}$ and S14). ${ }^{46,47,48}$ The position of the P $2 p$ peak at $133.2 \mathrm{eV}$ was consistent with phosphate species (Figure S14). ${ }^{49}$ Finally, the $\mathrm{O} 1 \mathrm{~s}$ spectrum consisted of two components centered at 531.7 and $533.8 \mathrm{eV}$ which were associated with $\mathrm{W}$ $\mathrm{O}-\mathrm{W}$ in thio-POM ${ }^{50}$ and $\mathrm{C}-\mathrm{O}-\mathrm{C}$ bonding in PEDOT, ${ }^{39}$ respectively. The experimental ratio between the areas under the $\mathrm{P} 2 \mathrm{p}$ and Mo $3 \mathrm{~d}$ peaks was estimated at 1.2 , in relatively 
close agreement with the theoretical ratio of 0.9 (8:9). Using tungsten as the characteristic element of thio-POM, we notice a nice agreement between the experimental $\mathrm{W} 4 \mathrm{~d}_{3 / 2} /$ Mo $3 \mathrm{~d}_{5 / 2}$ ratio of 5.2 and that theoretically expected, i.e. 5.3 (48:9).

Photoelectrocatalytic properties of 1b/PEDOT-coated SimPy were examined under similar conditions to those used for PEDOT-free flat $\mathrm{Si}$ photocathodes (Figure 4). A control experiment with a SimPy photocathode modified with a perchlorate-doped PEDOT film without catalyst revealed a cathodic peak at $0.18 \mathrm{~V}$ vs RHE corresponding to the conversion of the positively charged conducting PEDOT to its insulating neutral form (Figure 7). This photocathode exhibited a poor HER efficiency observed at $-0.3 \mathrm{~V}$ vs RHE while a better efficiency featured by higher photocurrents were measured for 1b/PEDOT-coated SimPy at low overpotentials. Plateau current density of $\sim 7 \mathrm{~mA} \mathrm{~cm}^{-2}$ was reached for potentials lower than $-0.38 \mathrm{~V}$ vs RHE. A careful examination of the LSV curve also evidenced a cathodic shoulder at ca. $0.12 \mathrm{~V}$ vs RHE which can be ascribed to the reduction of positively charged PEDOT to its neutral form. As the HER process occurs in a potential window wherein the polymer film becomes electronically insulating, electron hopping between the cocat sites should be considered as the main charge transport mechanism required for supplying the HER activity. Besides, intensive research on redox polymermodified electrodes has demonstrated that charge propagated through a redox polymer film by electron hopping was not necessarily limiting for efficient electrocatalysis. ${ }^{51}$ The cathodic photocurrent densities measured in the presence of PEDOT were however about 3.5 times weaker than those obtained on flat $\mathrm{Si}$ without PEDOT (Fig. 4) in spite of a higher electrochemical surface area. Such a trend is reasonably explained by the light absorption of the PEDOT film ${ }^{52}$ which substantially reduces light intensity transmitted to silicon and thus decreases the photocurrent densities.

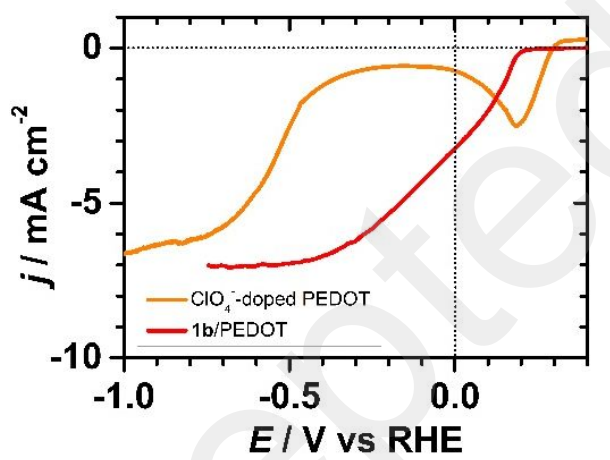

Figure 7. LSV curves at $20 \mathrm{mV} \mathrm{s}^{-1}$ of $\mathrm{ClO}_{4}^{-} / \mathrm{PEDOT}$ - and $\mathbf{1 b} / \mathrm{PEDOT}$ modified SimPy photocathodes under simulated sunlight (AM 1.5G, 100 $\mathrm{mW} \mathrm{cm}{ }^{-2}$ ) in $1.0 \mathrm{~mol} \mathrm{~L}^{-1} \mathrm{H}_{2} \mathrm{SO}_{4}$

This is supported by the total reflectance and incident photonto-current efficiency (IPCE) spectra. As shown in Figure 8a, the UV-visible reflectance of $1 \mathbf{b} /$ PEDOT-coated SimPy was much smaller than that measured for bare SimPy, 10-17\% against 15$35 \%$, but comparable to that of $\mathrm{ClO}_{4}^{-}$-doped PEDOT-coated SimPy, i.e. $10-12 \%$. This overall increase of light absorption was confirmed by the IPCE substantial decrease from about 90\% for unmodified SimPy (in close agreement with those previously reported $)^{53,54}$ to $22-27 \%$ after deposition of the 1b/PEDOT layer onto SimPy (Fig. 8b).
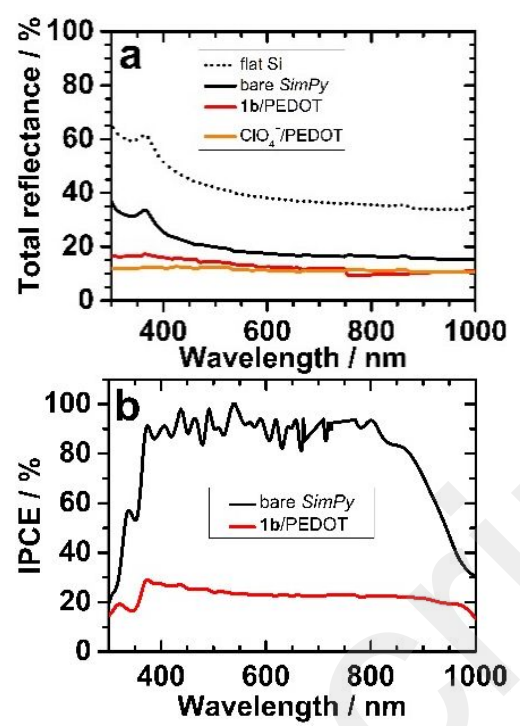

Figure 8. Total reflectance (a) and IPCE (b) spectra obtained for bare flat silicon (black dotted line), bare SimPy (black solid line), 1b/PEDOT (red line) and $\mathrm{ClO}_{4}{ }^{-} / \mathrm{PEDOT}$ (orange line) -modified SimPy. The ICPE spectra were recorded at $-0.54 \mathrm{~V}$ vs RHE for $\mathbf{1 b} /$ PEDOT-modified SimPy and -1.24 V vs RHE for bare SimPy.

However, the 1b/PEDOT-modified photocathode was found to operate fairly for sunlight-assisted HER at $0 \mathrm{~V}$ vs RHE. Stability in operation was investigated during controlledpotential electrolysis tests over a period of $3 \mathrm{~h}$. As shown in Figure 9, the modified photocathode yielded $\mathrm{H}_{2}$ with a rate of production of $100 \pm 10 \mu \mathrm{mol} \mathrm{cm} \mathrm{cm}^{-2} \mathrm{~h}^{-1}$ [detected by gas chromatography (GC)] and a faradaic efficiency of $94 \pm 2 \%$. After an initial period of about $30 \mathrm{~min}$, the measured photocurrent density remained relatively stable around $4.0 \mathrm{~mA}$ $\mathrm{cm}^{-2}$ during the electrolysis time. Furthermore, a stability test over a period exceeding $5 \mathrm{~h}$ did not show any noticeable degradation in the photocurrent (Figure S15). This stationary $4.0 \mathrm{~mA} \mathrm{~cm}{ }^{-2}$ value is in quite good agreement with that derived from the LSV curve at the tested potential (shown in Fig. 7). The slight decrease at the initial step in the cathodic current was caused probably by the reduction of positively charged PEDOT to its neutral form. Nevertheless, the similarity between the LSV curves before and after electrolysis (Fig. 9c) demonstrates the high stability of the 1b/PEDOT-modified photocathode and rules out any degradation of the catalyst during electrolysis.

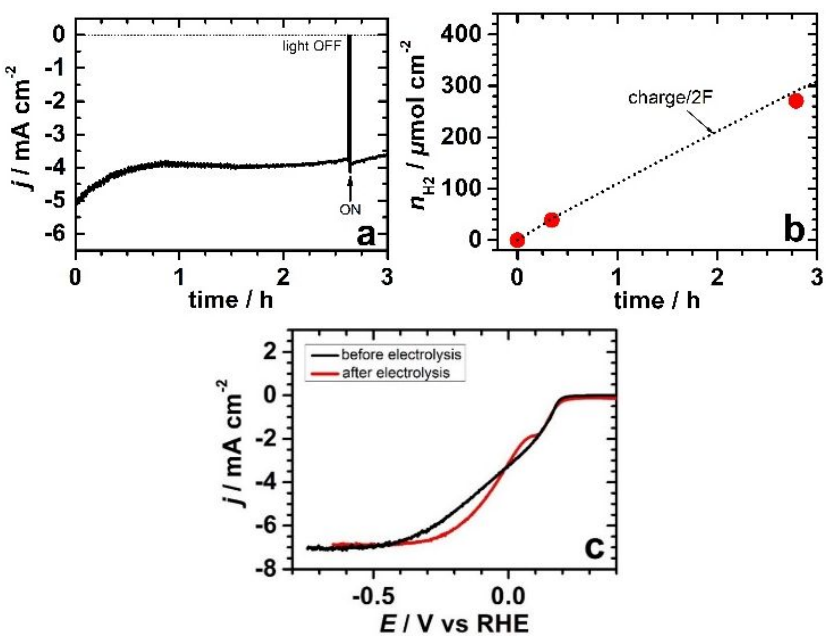

Figure 9. a) Photocurrent density-time curve obtained during the potentiostatic electrolysis at $0 \mathrm{~V}$ vs RHE using the 1b/PEDOT-coated 
SimPy photocathode under simulated sunlight (AM 1.5G, $100 \mathrm{~mW} \mathrm{~cm} \mathrm{~cm}^{-2}$ ). b) Amount of $\mathrm{H}_{2}$ evolved at the photocathode as a function of the electrolysis time. The mole number of produced gas was determined by GC. The dotted black line corresponds to the theoretical fit assuming a $100 \%$ Faradaic efficiency. c) LSV curves at $20 \mathrm{mV} \mathrm{s}^{-1}$ of $\mathbf{1 b} /$ PEDOT-coated SimPy before and after electrolysis at $0 \mathrm{~V}$ vs RHE.

\section{Conclusions}

In this study, we evidenced nicely that $\left\{\mathrm{P}_{8} \mathrm{~W}_{48}\right\}$-supported $\mathrm{Mo}_{3} \mathrm{~S}_{4}$ generates a striking HER synergistic effect compared with the parent moieties, leading to substantial decrease of the HER overpotential. Such an effect was first evidenced in homogenous solution using glassy carbon as the working electrode. Solution studies revealed that this synergy requires the direct interplay between both components i.e. the $\left\{\mathrm{Mo}_{3} \mathrm{~S}_{4}\right\}$ catalytic unit and the $\left\{\mathrm{P}_{8} \mathrm{~W}_{48}\right\}$ electron-collecting unit, arising from the covalent anchoring. Such $\left\{\mathrm{P}_{8} \mathrm{~W}_{48}\right\}$-supported $\left\{\mathrm{Mo}_{3} \mathrm{~S}_{4}\right\}$ molecular catalyst has been used as cocat for the preparation of modified silicon photocathodes showing that HER synergy is retained and even amplified in the heterogeneous electrochemical process. Furthermore, the use of a conjugated polymer film as the cocat-embedding matrix appears as a promising and scalable approach to retain the thio-POM active phase on the silicon photocathode in a durably functioning photocathode. Even though intrinsic limitations related to the partial light absorption by PEDOT reduces the catalytic efficiency, the modified photocathodes were found to operate efficiently for HER at $0 \mathrm{~V}$ vs RHE under simulated sunlight, producing approximately $100 \pm 10 \mu \mathrm{mol}$ of $\mathrm{H}_{2} \mathrm{~cm}^{-2} \mathrm{~h}^{-1}$. In addition, no decomposition of the catalytic material was observed over a test period of several hours highlighting the relevancy of the thio-POM materials as HER electrocatalyst. The thio-POM strategy opens many improvements or optimization that could be engineered at multi-scale steps such as $i$ ) the POM-cluster combination, $i i)$ the control of the catalytic material-electrode interface, iii) implementing the cocat entrapment procedure using adapted covering polymer (conducting, transparent, cationic or hydrophobic...).

\section{ASSOCIATED CONTENT}

Supporting Information. General methods, syntheses, FT-IR spectra, NMR data, electrochemical measurements, UV-visible spectra, preparation of the modified silicon surfaces, gas detection and general instrumentation such as Scanning Electron Microscopy (SEM), ICPE and XPS spectroscopy. The Supporting Information is available free of charge on the ACS Publications website via the Internet at http://pubs.acs.org.

\section{AUTHOR INFORMATION}

\section{Corresponding Author}

* bruno.fabre@univ-rennes1.fr

* emmanuel.cadot@uvsq.fr

\section{ACKNOWLEDGMENT}

The authors gratefully acknowledge ANR (Agence Nationale de la Recherche) for financial support of the CHALCO-CAT program (CHALCO-CAT, grant number ANR-15-CE06-0002-01). This work was supported by $i$ ) University of Rennes 1,ii) University of Versailles Saint Quentin, iii) CNRS and iv) the LabEx
CHARMMMAT of University Paris-Saclay (grant number ANR11-LABX-0039).

\section{REFERENCES}

(1) Cook, T. R.; Dogutan, D. K.; Reece, S. Y.; Surendranath, Y.; Teets, T. S.; Nocera, D. C. Solar Energy Supply and Storage for the Legacy and Nonlegacy Worlds. Chem. Rev. 2010, 110, 6474-6502.

(2) Lewis, N. S.; Nocera, D. G. Powering the Planet: Chemical Challenges in Solar Energy Utilization. Proc. Natl. Acad. Sci. USA 2006 , 103 ,1572915735.

(3) Walter, M. G.; Warren, E. L.; McKone, J. R.; Boettcher, S. W.; Mi, Q.; Santori, E. A.; Lewis, N. S. Solar Water Splitting Cells. Chem. Rev. 2010, $110,6446-6473$

(4) Sun, K.; Shen, S.; Liang, Y.; Burrows, P. E.; Mao, S. S.; Wang, D. Enabling Silicon for Solar-Fuel Production. Chem. Rev. 2014, 114, 86628719.

(5) Yao, T.; An, X.; Han, H.; Chen, J. Q.; Li, C. Photoelectrocatalytic Materials for Solar Water Splitting. Adv. Energy Mater. 2018, 8, 1800210. (6) Sivula, K.; van de Krol, R. Semiconducting Materials for Photoelectrochemical Energy Conversion. Nat. Rev. Mater. 2016, 1, 1-16.

(7) Morales-Guio, C. G.; Hu, X. Amorphous Molybdenum Sulfides as Hydrogen Evolution Catalysts. Acc. Chem. Res. 2014, 47, 2671-2681.

(8) Seger, B.; Laursen, A. B.; Vesborg, P. C. K.; Pedersen, T.; Hansen, O.; Dahl, S.; Chorkendorff, I. Hydrogen Production Using a Molybdenum Sulfide Catalyst on a Titanium-Protected $\mathrm{n}^{+} \mathrm{p}$-Silicon Photocathode. Angew. Chem. Int. Ed. 2012, 51, 9128-9131.

(9) Laursen, A. B.; Pedersen, T.; Malacrida, P.; Seger, B.; Hansen, O.; Vesborg, P. C.; Chorkendorff, I. $\mathrm{MoS}_{2}$ : An Integrated Protective and Active Layer on $\mathrm{n}(+) \mathrm{p}-\mathrm{Si}$ for Solar $\mathrm{H}_{2}$ Evolution. Phys. Chem. Chem. Phys. 2013, 15, 20000-20004.

(10) Tran, P. D.; Pramana, S. S.; Kale, V. S.; Nguyen, M.; Chiam, S. Y.; Batabyal, S. K.; Wong, L. H.; Barber, J.; Loo, J. Novel Assembly of an $\mathrm{MoS}_{2}$ Electrocatalyst onto a Silicon Nanowire Array Electrode to Construct a Photocathode Composed of Elements Abundant on the Earth for Hydrogen Generation. Chem. Eur. J. 2012, 18, 13994-13999.

(11) Ding, Q.; Meng, F.; English, C. R.; Caban-Acevedo, M.; Shearer, M. J.; Liang, D.; Daniel, A. S.; Hamer, R. J.; Jin, S. Efficient Photoelectrochemical Hydrogen Generation Using Heterostructures of $\mathrm{Si}$ and Chemically Exfoliated Metallic $\mathrm{MoS}_{2}$. J. Am. Chem. Soc. 2014, 136, 8504-8507.

(12) Ding, Q.; Zhai, J.; Caban-Acevedo, M.; Shearer, M. J.; Li, L.; Chang, H.-C.; Tsai, M.-L.; Ma, D.; Zhang, X.; Hamers, R. J.; He, J.-H.; Jin, S. Designing Efficient Solar-Driven Hydrogen Evolution Photocathodes Using Semitransparent $\mathrm{MoQ}_{\mathrm{x}} \mathrm{Cl}_{\mathrm{y}}(\mathrm{Q}=\mathrm{S}$, Se $)$ Catalysts on $\mathrm{Si}$ Micropyramids. Adv. Mater. 2015, 27, 6511-6518.

(13) Benck, J. D.; Lee, S. C.; Fong, K. D.; Kibsgaard, J.; Sinclair, R.; Jaramillo, T. F. Designing Active and Stable Silicon Photocathodes for Solar Hydrogen Production Using Molybdenum Sulfide Nanomaterials. Adv. Energy Mater. 2014, 4, 1400739.

(14) King, L. A.; Hellstern, T. R.; Park, J.; Sinclair, R.; Jaramillo, T. F. Highly Stable Molybdenum Disulfide Protected Silicon Photocathodes for Photoelectrochemical Water Splitting. ACS Appl. Mater. Interf. 2017, 9, 36792-36798.

(15) Kibsgaard, J.; Jaramillo, T. F.; Besenbacher, F. Building an Appropriate Active-Site Motif into a Hydrogen-Evolution Catalyst with Thiomolybdate $\left[\mathrm{Mo}_{3} \mathrm{~S}_{13}\right]^{2-}$ - Clusters. Nature Chem. 2014, 6, 248-253.

(16) Hellstern, T. R.; Kibsgaard, J.; Tsai, C.; Palm, D. W.; King, L. A.; Abild-Pedersen, F.; Jaramillo, T. F. Investigating Catalyst-Support Interactions to Improve the Hydrogen Evolution Reaction Activity of Thiomolybdate $\left[\mathrm{Mo}_{3} \mathrm{~S}_{13}\right]^{2-}$ Nanoclusters. ACS Catal. 2017, 7, 7126-7130.

(17) Hou, Y.; Abrams, B. L.; Vesborg, P. C. K.; Björketun, M. E.; Herbst, K.; Bech, L.; Setti, A. M.; Damsgaard, C. D.; Pedersen, T.; Hansen, O.; Rossmeisl, J.; Dahl, S.; Norskov, J. K.; Chorkendorff, I. Bioinspired Molecular Co-Catalysts Bonded to a Silicon Photocathode for Solar Hydrogen Evolution. Nature Mater. 2011, 10, 434-438.

(18) Seger, B.; Herbst, K.; Pedersen, T.; Abrams, B.; Vesborg, P. C. K.; Hansen, O.; Chorkendorff, I. $\mathrm{Mo}_{3} \mathrm{~S}_{4}$ Clusters as an Effective $\mathrm{H}_{2}$ Evolution Catalyst on Protected Si Photocathodes. J. Electrochem. Soc. 2014, 161, H722-H724.

(19) Rakowski DuBois, M. Catalytic Applications of Transition-Metal Complexes with Sulfide Ligands. Chem. Rev. 1989, 89, 1-9. 
(20) Launay, J.-P. Reduction of Metatungstate Ion. High Reduction Stages of $\left[\mathrm{H}_{2} \mathrm{~W}_{12} \mathrm{O}_{40}\right]^{6-}$ Derivatives of $\mathrm{HW}_{12} \mathrm{O}_{40}{ }^{7-}$ and General Discussion. J. Inorg. Nucl. Chem. 1976, 38, 807-816.

(21) Sadakane, M.; Steckhan, E. Electrochemical Properties of Polyoxometalates as Electrocatalysts. Chem. Rev. 1998, 98, 219-237.

(22) Ueda, T. Electrochemistry of Polyoxometalates: From Fundamental Aspects to Applications. ChemElectroChem 2018, 5, 823-838.

(23) Wang, H.; Hamanaka, S.; Nishimoto, Y.; Irle, S.; Yokoyama, T.; Yoshikawa, H.; Awaga, K. In Operando X-Ray Absorption Fine Structure Studies of Polyoxometalate Molecular Cluster Batteries: Polyoxometalates as Electron Sponges. J. Am. Chem. Soc. 2012, 134, 4918-4924.

(24) Sokolov, M. N.; Kalinina, I. V.; Peresypkina, E. V.; Cadot, E.; Tkachev, S. V.; Fedin, V. P. Incorporation of Molybdenum Sulfide Cluster Units into a Dawson-Like Polyoxometalate Structure To Give Hybrid Polythiooxometalates. Angew. Chem. Int. Ed. 2008, 47, 1465-1468.

(25) Cadot, E.; Sokolov, M. N.; Fedin, V. P.; Simonnet-Jégat, C.; Floquet, S.; Sécheresse, F. A Building Block Strategy to Access SulfurFunctionalized Polyoxometalate Based Systems using $\left\{\mathrm{Mo}_{2} \mathrm{~S}_{2} \mathrm{O}_{2}\right\}$ and $\left\{\mathrm{Mo}_{3} \mathrm{~S}_{4}\right\}$ as Constitutional Units, Linkers or Templates. Chem. Soc. Rev. 2012, 41, 7335-7353.

(26) Fu, D.; Fabre, B.; Loget, G.; Meriadec, C.; Ababou-Girard, S.; Cadot, E.; Leclerc-Laronze, N.; Marrot, J.; de Ponfilly, Q. PolyoxothiometalateDerivatized Silicon Photocathodes for Sunlight-Driven HER. ACS Omega 2018, 3, 13837-13849.

(27) Bao, X.-Q.; Petrovykh, D. Y.; Alpuim, P.; Stroppa, D. G.; Guldris, N.; Fonseca, H.; Costa, M.; Gaspar, J.; Jin, C.; Liu, L. Amorphous OxygenRich Molybdenum Oxysulfide Decorated p-Type Silicon Microwire Arrays for Efficient Photoelectrochemical Water Reduction. Nano Energy 2015 $16,130-142$

(28) Truong, T.-G.; Mériadec, C.; Fabre, B.; Bergamini, J.-F.; de Sagazan, O.; Ababou-Girard, S.; Loget, G. Spontaneous Decoration of Silicon Surfaces with $\mathrm{MoO}_{\mathrm{x}}$ Nanoparticles for the Sunlight-Assisted Hydrogen Evolution Reaction. Nanoscale 2017, 9, 1799-1804.

(29) Contant, R.; Teze, A. A New Crown Heteropolyanion $\mathrm{K}_{28} \mathrm{Li}_{5} \mathrm{H}_{7} \mathrm{P}_{8} \mathrm{~W}_{48} \mathrm{O}_{184} \cdot 92 \mathrm{H}_{2} \mathrm{O}$ : Synthesis, Structure, and Properties. Inorg. Chem. 1985, 24, 4610-4614.

(30) Haouas M.; Diab, M.; Moussawi, M. A.; Cadot, E.; Floquet, S.; Henry, M.; Taulelle, F. Investigation of the Protonation State of the Macrocyclic $\left\{\mathrm{H}_{n} \mathrm{P}_{8} \mathrm{~W}_{48} \mathrm{O}_{184}\right\}$ Anion by Modeling ${ }^{183} \mathrm{~W}$ NMR Chemical Shifts. New J. Chem. 2017, 41, 6112-6119.

(31) Boyd, T.; Mitchell, S. G.; Gabb, D.; Long, D.-L.; Song, Y.-F.; Cronin, L. POMzites: A Family of Zeolitic Polyoxometalate Frameworks from a Minimal Building Block Library. J. Am. Chem. Soc. 2017, 139, 5930-5938. (32) Bassil, B. S.; Ibrahim, M.; Mal, S. S.; Suchopar, A.; Biboum, R. N.; Keita, B.; Nadjo, L.; Nellutla, S.; van Tol, J.; Dalal, N. S.; Kortz, U. Cobalt, Manganese, Nickel, and Vanadium Derivatives of the Cyclic 48-Tungsto8-Phosphate $\left[\mathrm{H}_{7} \mathrm{P}_{8} \mathrm{~W}_{48} \mathrm{O}_{184}\right]^{33-}$. Inorg. Chem. 2010, 49, 4949-4959.

(33) Zimmermann, M.; Belai, N.; Butcher, R. J.; Pope, M. T.; Chubarova, E. V.; Dickman, M. H.; Kortz, U. New Lanthanide-Containing Polytungstates Derived from the Cyclic $\mathrm{P}_{8} \mathrm{~W}_{48}$ Anion: $\left\{\mathrm{Ln}_{4}\left(\mathrm{H}_{2} \mathrm{O}\right)_{28}\left[\mathrm{~K} \subset \mathrm{P}_{8}\right.\right.$ $\left.\left.\mathrm{W}_{48} \mathrm{O}_{184}\left(\mathrm{H}_{4} \mathrm{~W}_{4} \mathrm{O}_{12}\right)_{2} \mathrm{Ln}_{2}\left(\mathrm{H}_{2} \mathrm{O}\right)_{10}\right]^{13-}\right\}_{x}, \mathrm{Ln}=\mathrm{La}, \mathrm{Ce}, \mathrm{Pr}, \mathrm{Nd}$. Inorg. Chem. 2007, 46, 1737-1740.

(34) Sousa, F. L.; Bögge, H.; Merca, A.; Gouzerh, P.; Thouvenot, R.; Müller, A. Vectorial Growth/Regulations in a $\left\{\mathrm{P}_{8} \mathrm{~W}_{48}\right\}$-Type Polyoxotungstate Compartment: Trapped Unusual Molybdenum Oxide Acts as a Handle. Chem. Commun. 2009, 7491-7493.

(35) Korenev, V. S.; Floquet, S.; Marrot, J.; Haouas, M.; Mbomekallé, I.M.; Taulelle, F.; Sokolov, M. N.; Fedin, V. P.; Cadot, E. Oxothiomolybdenum Derivatives of the Superlacunary Crown Heteropolyanion $\left\{\mathrm{P}_{8} \mathrm{~W}_{48}\right\}$ : Structure of $\left[\mathrm{K}_{4}\left\{\mathrm{Mo}_{4} \mathrm{O}_{4} \mathrm{~S}_{4}\left(\mathrm{H}_{2} \mathrm{O}\right)_{3}(\mathrm{OH})_{2}\right\}_{2}\right.$ $\left.\left(\mathrm{WO}_{2}\right)\left(\mathrm{P}_{8} \mathrm{~W}_{48} \mathrm{O}_{184}\right)\right]^{30-}$ and Studies in Solution. Inorg. Chem. 2012, 51, 2349-2358.

(36) Keita, B.; Lu, Y. W.; Nadjo, L.; Contant, R. Salient Electrochemical and Electrocatalytic Behaviour of the Crown Heteropolyanion $\mathrm{K}_{28} \mathrm{Li}_{5} \mathrm{H}_{7} \mathrm{P}_{8} \mathrm{~W}_{48} \mathrm{O}_{184} \cdot 92 \mathrm{H}_{2} \mathrm{O}$. Electrochem. Commun. 2000, 2, 720-726.

(37) Kristensen, J.; Zhang, J. D.; Chorkendorff, I.; Ulstrup, J.; Ooi, B. L. Assembled Monolayers of $\mathrm{Mo}_{3} \mathrm{~S}_{4}{ }^{4+}$ Clusters on Well-Defined Surfaces. Dalton Trans. 2006, 3985-3990.

(38) Spanninga, S. A.; Martin, D. C.; Chen, Z. X-Ray Photoelectron Spectroscopy Study of Counterion Incorporation in Poly(3,4Ethylenedioxythiophene) (PEDOT). 2: Polyanion Effect, Toluenesulfonate, and Small Anions. J. Phys. Chem. C 2010, 114, 14992-14997.

(39) Spanninga, S. A.; Martin, D. C.; Chen, Z. X-Ray Photoelectron Spectroscopy Study of Counterion Incorporation in $\operatorname{Poly}(3,4-$
Ethylenedioxythiophene). J. Phys. Chem. C 2009, 113, 5585-5592.

(40) Jönsson, S. K. M.; de Jong, M. P.; Groenendaal, L.; Salaneck, W. R.; Fahlman, M. Phenyl-Capped EDOT Trimer: Its Chemical and Electronic Structure and Its Interface with Aluminum. J. Phys. Chem. B 2003, 107, 10793-10800.

(41) Khan, M. A.; Armes, S. P.; Perruchot, C.; Ouamara, H.; Chehimi, M. M.; Greaves, S. J.; Watts, J. F. Surface Characterization of Poly $(3,4-$ Ethylenedioxythiophene)-Coated Latexes by X-Ray Photoelectron Spectroscopy. Langmuir 2000, 16, 4171-4179.

(42) Baltrusaitis, J.; Mendoza-Sanchez, B.; Fernandez, V.; Veenstra, R.; Dukstiene, N.; Roberts, A.; Fairley, N. Generalized Molybdenum Oxide Surface Chemical State XPS Determination via Informed Amorphous Sample Model. Appl. Surf. Sci. 2015, 326, 151-161.

(43) Bruce, J. P.; Oliver, D. R.; Lewis, N. S.; Freund, M. S. Electrical Characteristics of the Junction between PEDOT:PSS and ThiopheneFunctionalized Silicon Microwires. ACS Appl. Mater. Interfaces 2015, 7, 27160-27166

(44) Merki, D.; Fierro, S.; Vrubel, H.; Hu, X. Amorphous Molybdenum Sulfide Films as Catalysts for Electrochemical Hydrogen Production in Water. Chem. Sci. 2011, 2, 1262-1267.

(45) Weber, T.; Muijsers, J. C.; Niemantsverdriet, J. W. Structure of Amorphous $\mathrm{MoS}_{3}$. J. Phys. Chem. 1995, 99, 9194-9200.

(46) Souza, A. L.; Tremiliosi Filho, G.; Kubota, L. T.; Mendes, R. K.; Botelho do Rego, A. M.; Oliveira, Jr, O. N.; Henry de Villeneuve, C.; Chazalviel, J. N.; Allongue, P.; Ozanam, F.; Rodrigues Filho, U. P. Poly(Dimethylsiloxane) as a Pre-Coating in Layer-by-Layer Films Containing Phosphotungstate Nanoclusters Electrochemically Sensitive Toward s-Triazines. RSC Adv. 2014, 4, 29612-29621.

(47) Yi, Z.-H.; Cui, X.-B.; Zhang, X.; Chen, Y.; Xu, J.-Q.; Yang, G.-D.; Liu, Y.-B.; Yu, X.-Y.; Yu, H.-H.; Duan, W.-J. A Novel 2D Layer Structural Compound Constructed from Tetra-Capped Pseudo-Keggin Heteropolytungstates interacting with Copper Coordination Fragments: $\left[\mathrm{Cu}(\mathrm{en})_{2}\left(\mathrm{H}_{2} \mathrm{O}\right)\right]_{2}\left[\mathrm{Cu}(\mathrm{en})_{2}\right]_{2}\left[\mathrm{AsW}_{2}{ }^{\mathrm{VI}} \mathrm{W}_{7}{ }^{\mathrm{V}} \mathrm{V}_{7}{ }^{\mathrm{IV}} \mathrm{O}_{44}\right] \bullet 2 \mathrm{H}_{2} \mathrm{O}$. Inorg. Chem. Commun. 2007, 10, 1448-1452.

(48) Chen, W.-C.; Li, H.-L.; Wang, X.-L.; Shao, K.-Z.; Su, Z.-M.; Wang, E.-B. Assembly of Cerium(III)-Stabilized Polyoxotungstate Nanoclusters with $\mathrm{SeO}_{3}{ }^{2-} / \mathrm{TeO}_{3}{ }^{2-}$ Templates: From Single Polyoxoanions to Inorganic Hollow Spheres in Dilute Solution. Chem. Eur. J. 2013, 19, 11007-11015. (49) X-Ray Photoelectron Spectroscopy Database, NIST Standard Reference Database 20, Version 4.1, National Institute of Standards and Technology NIST, https://srdata.nist.gov/xps/Default.aspx, last updated: September 15, 2012.

(50) Isahak, W. N. R. W.; Ramli, Z. A. C.; Ismail, M.; Yarmo, M. A. Highly Selective Glycerol Esterification over Silicotungstic Acid Nanoparticles on Ionic Liquid Catalyst. Ind. Eng. Chem. Res. 2014, 53, 10285-10293.

(51) Andrieux, C. P.; Savéant, J.-M. In Molecular Design of Electrode Surfaces; Murray, R. W., Ed.; Techniques of Chemistry Series, Vol. XXII, Wiley \& Sons, Inc., New York, pp 207-270, 1992.

(52) Gustafsson, J. C.; Liedberg, B.; Inganäs, O. In Situ Spectroscopic Investigations of Electrochromism and Ion Transport in a Poly(3,4Ethylenedioxythiophene) Electrode in a Solid State Electrochemical Cell. Solid State Ionics 1994, 69, 145-152.

(53) Andoshe, D. M.; Choi, S.; Shim, Y.-S.; Lee, S. H.; Kim, Y.; Moon, C. W.; Kim, D. H.; Lee, S. Y.; Kim, T.; Park, H. K.; Lee, M. G.; Jeon, J.-M.; Nam, K. T.; Kim, M.; Kim, J. K.; Oh, J.; Jang, H. W. A Wafer-Scale Antireflective Protection Layer of Solution-Processed $\mathrm{TiO}_{2}$ Nanorods for High Performance Silicon-Based Water Splitting Photocathodes. J. Mater. Chem. A 2016, 4, 9477-9485.

(54) Oh, J.; Deutsch, T. G.; Yuan, H.-C.; Branz, H. M. Nanoporous Black Silicon Photocathode for H2 Production by Photoelectrochemical Water Splitting. Energy Environ. Sci. 2011, 4, 1690-1694. 


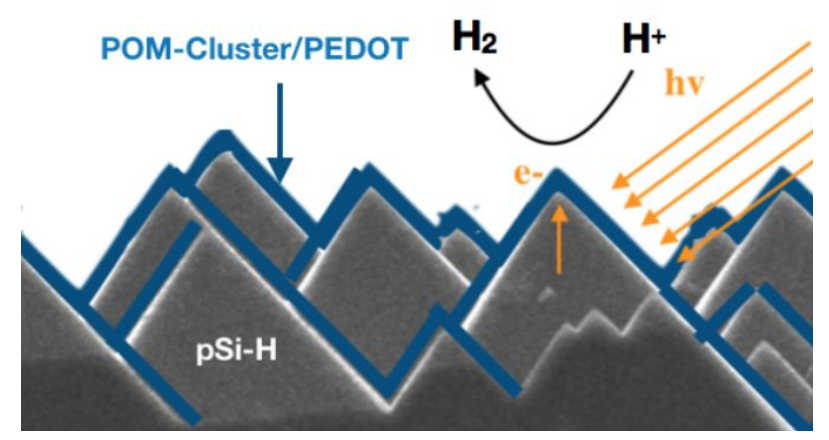

